\title{
DOES THE ABUNDANCE OF NATURAL RESOURCES CROWD-OUT THE MANUFACTURING SECTOR? EVIDENCE FROM NIGERIA
}

Nzeh Innocent
Chile $^{1^{+}}$
(D) Benedict I.
Uzoechina $^{2}$
(D) Millicent Adanne
Eze $^{3}$
(D) Chika P.
Imoagwu
(iD Uzoma M.
Anyachebelu

\section{Article History}

Received: 28 June 2021 Revised: 30 July 2021 Accepted: 19 August 2021 Published: 14 September 2021

\section{Keywords}

Natural resources endowment Manufacturing value added Dutch disease ARDL

Labour force

Production function.

JEL Classification: O13; L60; O40,

\author{
'Department of Economics, Renaissance University, Ugbawka, Enugu State, \\ Nigeria. \\ 'Email:nzechile@yahoo.com Tel: +234-8034222084 \\ ${ }^{2,2}$ Department of Economics, Nnamdi Azikiwe University, Awka, Anambra \\ State, Nigeria. \\ _EMail: ib.uzoechina@unizik.edu.ng Tel: +234-8063304867 \\ "Email:pc.imoagron@unizik.edu.ng Tel:+234-8035774516 \\ ${ }^{s}$ School of Business and Social Sciences, Abertay University, Dundee, United \\ Kingdom. \\ ${ }^{3}$ Email:ezemillicent@gmail.com Tel: (+44)7459452103 \\ ${ }^{5}$ Department of Economics, Nwafor Orizu College of Education, Nsugbe, \\ Anambra State, Nigeria. \\ Email:zommym@gmail.com Tel:+234-803345496
}

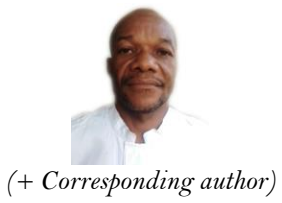

(+ Corresponding author)

\section{ABSTRACT}

Our objective in this study is to investigate if natural resource abundance can crowedout the manufacturing sector in Nigeria. Under the framework of an ARDL and over a period of 1990-2019, findings of the results showed that in the short-run, natural resources positively impact on the manufacturing value added in the current period; however, after a one period lag, the contribution of natural resources to the manufacturing value added becomes negative. We also found that in the short-run, real interest rate, inflation rate and trade openness are negatively linked to the manufacturing value added, while employment in industry and gross fixed capital formation are positively related to the manufacturing value added. In the long-run, natural resources contributed positively to the manufacturing value added. The longrun results also show that the gross fixed capital formation and inflation rate negatively impact on the manufacturing valued added. The implication of our finding is that natural resources rent is closely linked to the success of the manufacturing sector and as such can also crowd-out the manufacturing sector. On grounds of these findings, we recommend, among others; that the proceeds from natural resources should be used to build critical infrastructure necessary to improve the performance of the manufacturing sector. This way, the economy can be diversified to create the needed employment.

Contribution/ Originality: This study contributes to the existing literature by investigating the link between the manufacturing sector performance and natural resources endowment in Nigeria.

\section{BACKGROUND TO THE STUDY}

Nigeria falls among the sub -Saharan African countries with an abundance of natural resources; including oil and gas as well as a host of solid minerals scattered across the country. The country is still grappling with proper development and management of the solid minerals as she concentrates mainly on the oil sector which contributes a large chunk to her Gross Domestic Product (GDP). In terms of economic development, the country is still lagging behind despite the huge revenues she generates from the sale of oil over the years. Just like most developing 
countries with huge presence of natural resources, the level of economic transformation is still very low and this is largely due to lack of diversification of the economy away from the oil sector, particularly the development of the manufacturing sector. Unlike some major oil producing countries such as Norway that uses her revenue from oil to develop critical infrastructure that boosts the industrial sector, revenues from oil are frittered away. Even when efforts were made to encourage savings from the excess crude through the introduction of the Excess Crude Account, such effort was thwarted by politicians who were hell-bent to monetize every proceed from the sale of oil.

Prior to gaining independence in 1960, the country's economy was at an embryonic stage with little or nonexistent manufacturing or industrial sector. Agriculture dominated the economy along with services sector and trading companies that were merely serving the interest of the colonial masters. The requisite infrastructure meant to boost productivity was also non-existent just as there were no institutions in place to encourage industrialization. After independence in 1960, the country made deliberate efforts to encourage industrialization. For instance, the Development plans of 1960-1985 contained measures to boost the industrial sector. The initiation of the Import-Substitution Industrialization Policy (ISIP) as well as the indigenization policy was efforts geared towards achieving this aim as encapsulated in the Development plans. Owing to the decline in the international price of crude oil around the early eighties, the country introduced stabilization policies meant among others, to diversify the economy, reduce high imports and to cushion the gap in raw materials.

The Structural Adjustment Programme (SAP) introduced around mid-eighties was pursued as a medium-term framework designed to tackle inherent weaknesses in the economy through the realignment of the structure of the economy to achieve productivity in the industrial sector. Nwaogwugwu, Ayodele, and Ejumedia (2016) observed that from 1994-1998; attempts to encourage private-sector led industrialization include the introduction of a dual exchange rate system in addition to other trade policies. The paper also contended that between 1999-2011, various economic reforms, including the National Economic Empowerment and Development Strategy (NEEDS), the Seven Point Agenda, Vision 2010 and a host of others were put in place to diversify the economy away from the oil sector.

Beginning from 2015 when a new regime came into power, implementation of protectionist policies became rampant. This is argued to boost domestic productivity by discouraging importation. In recent times, one of such protectionist policies is the border closure which was implemented in 2019. Also, the government went ahead to make a list of 44 imported goods to be banned from access to CBN's official exchange rate. Though these policies were meant to boost domestic productivity, the aftermath of their implementation was rising inflation as local production of the banned commodities, especially rice; cannot meet local demand of the commodity. Despite all these efforts, the manufacturing sector in Nigeria has been lagging behind compared to other countries which had similar development history with her such as Malaysia, Singapore and other South East Asian countries. Nwaogwugwu et al. (2016) were of the opinions that among the factors impeding the manufacturing sector in Nigeria include: poor state of roads, dysfunctional rail system, low electricity generation, institutional bottlenecks, corruption, over-bloated bureaucracy and neglect of the agricultural sector:

This study is therefore motivated by the poor performance of the manufacturing sector over the years and the role played by Nigeria's natural resources endowment in shaping the manufacturing sector. We seek to investigate if crowding-out effect of natural resources on the manufacturing sector exists in Nigeria as it has been noted that an abundant natural resources could displace the manufacturing sector. The dearth of research in this area, especially in Nigeria equally served as a motivating factor for the choice of the topic. A preponderance of studies involving Nigeria mainly focused on the impact of natural resource endowments on the country's GDP (Amusa, 2016; Ewubare \& Kakain, 2017; Fatai, Adeolu, \& Ayo, 2017; Kareem, Arije, Zakariyah, \& Avovome, 2020). Therefore, by focusing on natural resource endowments and the manufacturing sector, we intend to fill the observed gap in literature. 


\subsection{A Profile of the Nigerian Economy}

Nigeria is a country blessed with an abundance of resources in terms of solid minerals, hydrocarbons and favourable soil and she also enjoys climatic condition that can sustain all-year round farming. According to the 2015 report by the Energy Information and Administration (EIA, 2015), Nigeria is the third largest producer of bioenergy, after China and India, respectively. The report equally noted that in 2010, over 80 per cent of the total primary energy supply came from bioenergy. In 2011, she had 37,200 million barrels of proven recoverable reserves; while in the same period oil production was 881,066 thousand barrels. Oil reserves in Nigeria stand at about 35 billion barrels and gas reserves is estimated to be around 5 trillion cubic metres. Thus, the country ranks as the $10^{\text {th }}$ oil producer and the $9^{\text {th }}$ natural gas producer in the world. In the African continent, Nigeria has the second largest proven oil reserves after Libya. Oil and gas deposits are located in the country's Niger Delta region, namely: Akwa Ibom, Delta, Rivers, Bayelsa, Cross River, Imo, Abia, Ondo and Edo states.

Apart from the presence of oil and gas, Nigeria has large deposits of coal, iron ore, lead, limestone, tin, zinc and other solid minerals. As noted by Okorafor (2014), Nigeria has rich land and water resources that support agricultural productivity. The study noted that approximately $83.7 \%$ of Nigeria's land area is agricultural, although only $40 \%$ is arable. Substantial water resources also assist the agricultural sector. Table 1 below shows the sold mineral deposits and their locations in Nigeria.

Table-1. Solid Minerals deposits in Nigeria.

\begin{tabular}{l|l|l}
\hline Solid mineral & Quantity (in Tons) & Location \\
\hline Talc & Over 40 million & Niger, Osun, Kogi, Ogun and Kaduna \\
\hline Gypsum & Over I billion & All over Nigeria \\
\hline Iron ore & Over 3 billion & Kogi, Enugu, Niger and FCT \\
\hline Lead/Zinc & 10 million (estimated) & Over 8 states \\
\hline Bentonite & 7 million & Many states \\
\hline Barite & Over 7.5 million & Taraba and Bauchi \\
\hline Gold & Not mentioned & Southern Western Nigeria \\
\hline Bitumen & 42 billion & Not mentioned \\
\hline Coal & $\begin{array}{l}\text { Nearly 3 billion indicated and over 600 million } \\
\text { proven reserves }\end{array}$ & \\
\hline Rock and salt & 1.5 million & Benue, Plateau and Ebonyi \\
\hline Source: Adapted from Okorafor $(2014)$. &
\end{tabular}

In another vein, the manufacturing sector in Nigeria has been experiencing hiccups over the years. As has been noted earlier, so many factors have been raised to account for the poor performance of this sector. Nigeria is a net importer of manufactured goods which gulps a larger share of her foreign exchange earnings. A seamless importation of foreign goods is capable of displacing the locally manufactured goods.

Figure 1 shows that over the years, the import of manufacture as a percentage of total merchandise imports has been displaying rising trend, though with some periods of falling trend. Compared this trend with the trend in export of manufacture as a percentage of total merchandise exports in Figure 2, evidence shows that the export of manufactures have not been faring well.

With the exception of 2008, 2010 and 2015 when it achieved some peaks, other years have been showing downward trend. The export of manufactures assumes a falling trend from 2011 through 2014 when it experienced rising trend. However, within these periods, the import of manufactures, even though assumed a falling trend from 2011 , rose from 2012 and again from 2014.

In Figure 3, the trend in total natural resource rent as a percentage of GDP has been fluctuating over the sample period. It got to a peak in 2000 and in 2005, 2008 and 2011, respectively it achieved peaks. Worthy of note is the fluctuating nature of the trend which indicates the volatile nature of natural resources revenue. Compared to the trend of manufacturing value added in Figure 4, it is evident that as the total natural resource rent as a percentage of GDP rise and fall, that of manufacturing value added as a percentage of GDP continuous to observe a falling 
trend over the sample period. The implication of the volatile nature of the natural resource rent is that its contribution to GDP is not sustainable as it depends on exogenous price shocks.
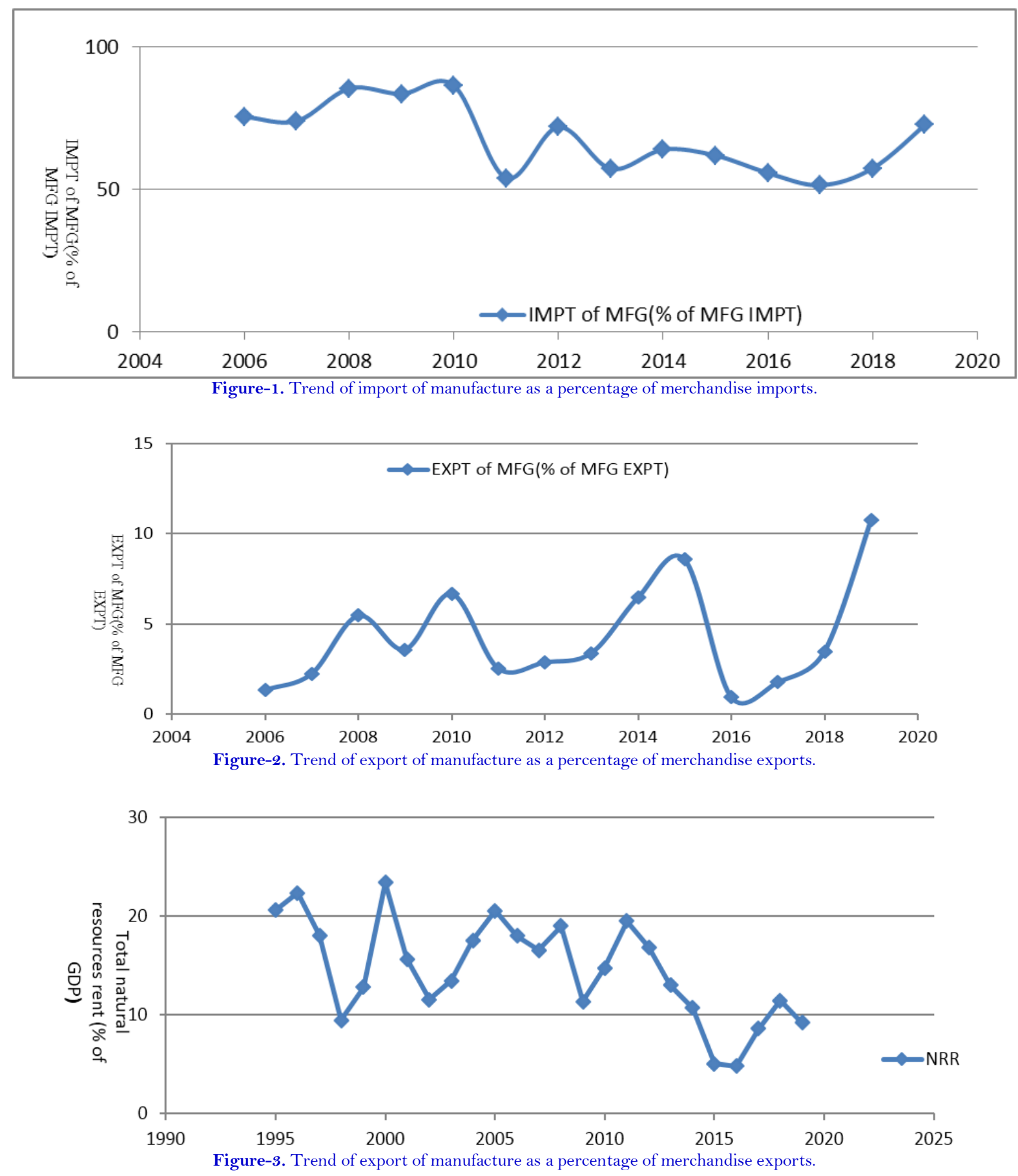

In another vein, the contribution of the manufacturing sector to the country's GDP has been insignificant over the years. As can be gleaned from Figure 4, the manufacturing value added as a percentage of GDP has been falling within the period under review. Beginning from the sample period of 2006, the index has been on the falling trend, except around 2010 up to 2014 when it slightly rose. This coincides with the period when the country's GDP was rebased and which placed Nigeria's GDP on top of other African countries. A closer look shows that the period when manufacturing value added rose corresponds to the period when the export of manufacture grew as shown in Figure 2 above. 


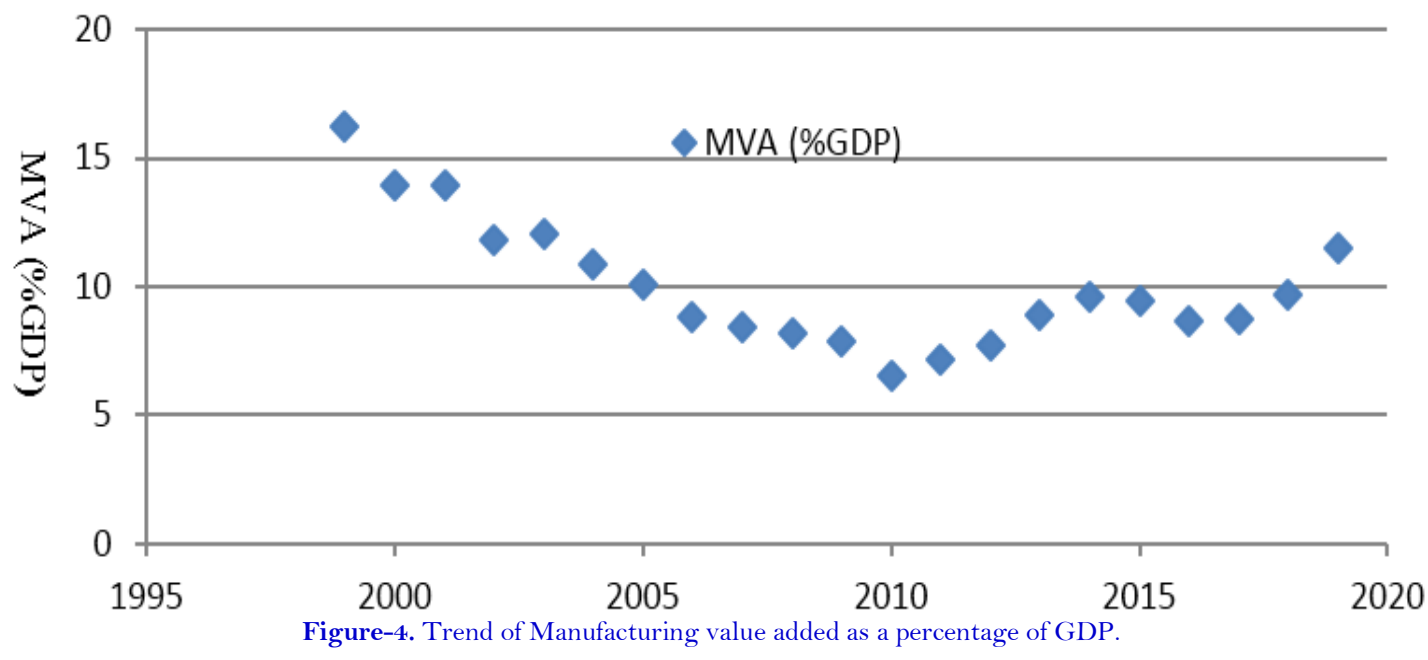

Access to credit is a major factor that spurs the development of the manufacturing sector. The manufacturing sector in Nigeria has been beset with the problem of access to credit over the years. Paucity of funds makes it impossible for expansion and engagement in research and development which are necessary in achieving export competitiveness. Figure 5 below shows that credit to the private sector as a percentage of GDP has been on the decline over the period. With the exception of around 2009 when the index rose slightly, other years have been exhibiting falling trend. Government borrowing in the economy has been one of the reasons why extending credit to the private sector is difficult as this crowds out private sector borrowing. The implication of this is that financing the manufacturing sector in the country faces setback.

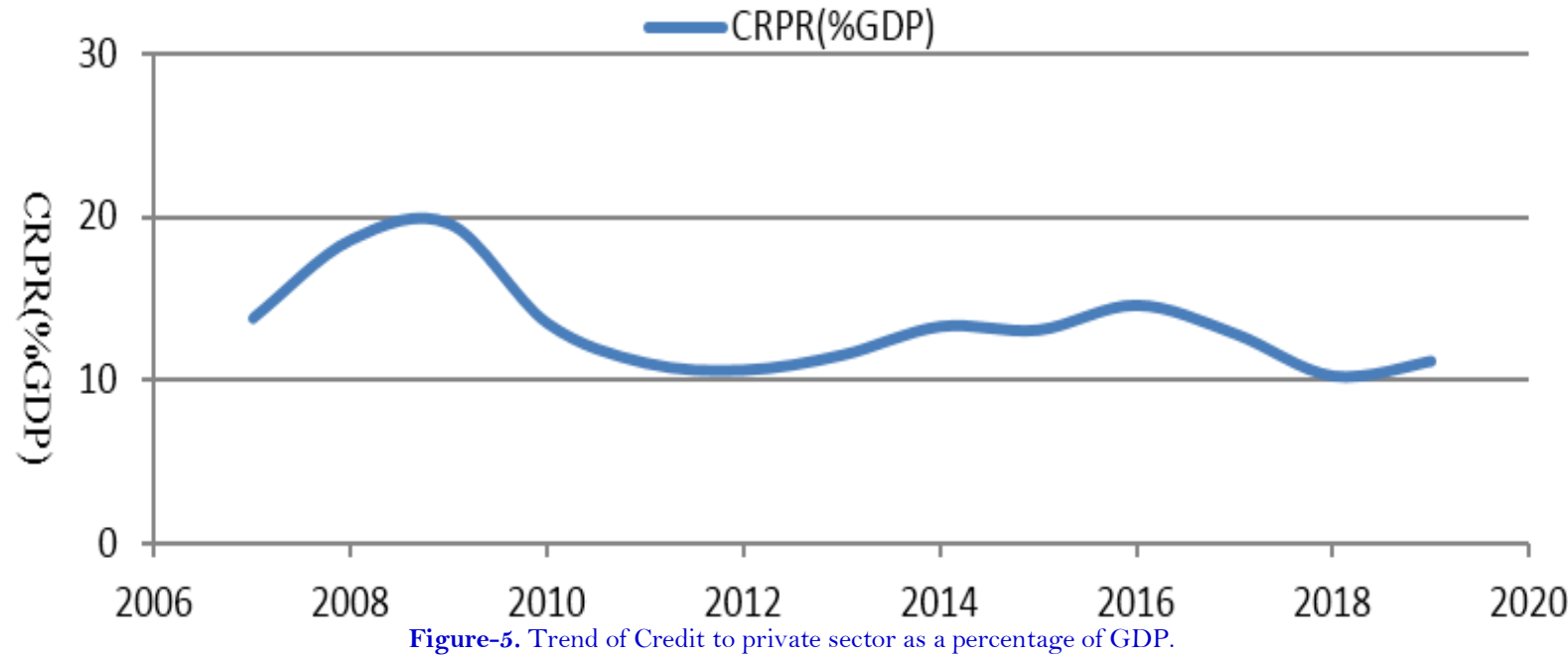

In terms of growth rate of GDP, Nigeria has not been performing better in relation to other natural resourcerich sub-Saharan African (SSA) countries. Figure 6 shows that Mauritania topped the countries with the highest rate of GDP growth rate between 2004 and 2006, followed by Zambia and Botswana. Between 2008 and 2010 , Zambia achieved the highest growth rate. Nigeria came second within this period only up to 2009 as Botswana topped the second chart in 2010. Between 2010 and 2014, Sierra Leone achieved the highest growth rate. Both Congo Democratic Republic and Zambia came second between 2011 and 2012. However, from 2012 up to 2014 , Botswana took over the second position. The worst performing period for Nigeria was from 2015 when the growth rate of GDP experienced continues decelerating trend and this coincides with the period of a change of government. 


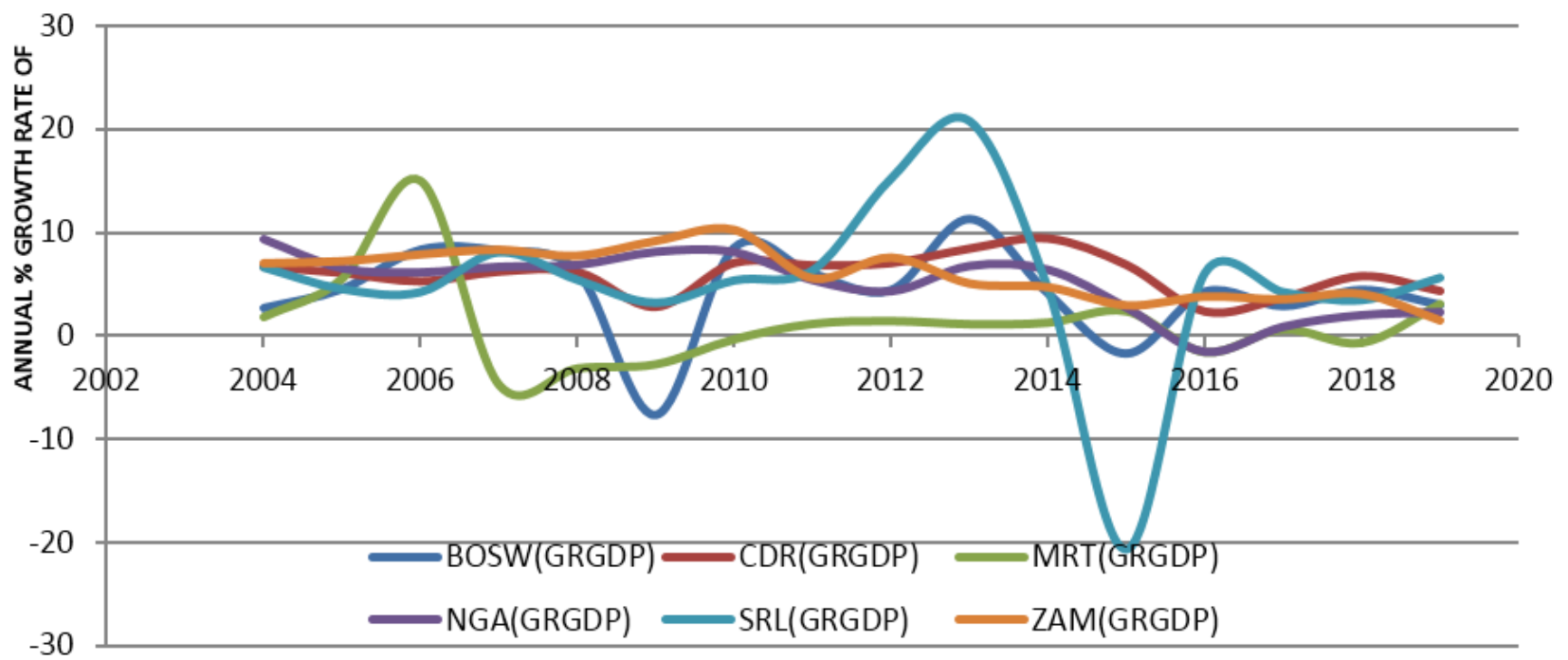

Figure-6. Trend in annual growth rate of GDP for some Sub-Saharan African natural resources rich countries.

Appendixes 1-6 display information on some institutional variables which we think are likely to influence the performance of the manufacturing sector. Starting from the index on the time required to get electricity (days) in Appendix 1. It should be seen that Nigeria ranks highest in this index as she spends an average of 149 days to get electricity, while some countries such as Botswana and Congo Democratic Republic spend 77 and 44 days on average to get electricity. It is obvious that without constant electricity, the economy, especially the manufacturing sector hardly performs well. Another index we considered is time to export; that is, documentary compliance (in hours). This index has to do with border compliance. Border compliance has to do with the time and cost involved in complying with a country's customs regulations. It also involves regulations relating to other inspections which are necessary for the shipment to cross the economy's border, including the time and cost for handling that takes place at its port or border. As shown in Appendix 2 below, it takes Nigeria an average of 131 hours to comply with border issues, while for countries such as Botswana and Mauritania, 18 and 50 hours are required respectively to achieve similar objective. In another vein, information on ease of doing business as shown in Appendix 3 shows that Mauritania and Zambia perform better in this regard.

\section{LITERATURE REVIEW}

In this study, we reviewed some related theories and empirical works that guided the achievement of the objectives.

\subsection{Theoretical Issues Associated with Natural Resources Endowment}

Over the years, several theories have been raised to discuss the concept of natural resource endowments and how it influences the growth path of countries that have it in abundance. It has been observed by some economists that the abundance of natural resources, if not well harnessed could crowd out some vital sectors of the economy. Sachs and Warner (2001) contended that the existence of natural resources could turn into a curse if they tend to crowd out some vital sectors of the economy. They are of the view that such sector is likely to be the manufacturing sector. Accordingly, undue attention to a dominant natural resource sector can crowd-out the traded-manufacturing industries and such development could permanently stagnate the economy. As it is always the case with natural resources dependent countries, such as Nigeria, this theoretical postulation contend that gains accruing from the exploitation of natural resources only benefits a tiny population at the expense of the rest of the population. Worst still, the beneficiaries hardly invest in the economy as they quickly spend the revenues from the export of these resources on unproductive ventures. The ways in which the revenues are spent raise the demand and thus the prices of non-tradable goods and services such as wages. With such rising prices, the manufacturing sector which uses the 
non-tradables and domestic labour as inputs in the production process can hardly compete on the world market as all these will increase production cost.

In a related vein, crowding out effect can be extended to investment in human capital. The key argument under this is that with rising wage and its depressing effect on manufacturing which makes it unprofitable, the urge to invest in education reduces. Gylfason (2001) was of the view that the performance of the economy does not necessarily depend on the existence of natural resources, however this depends on the way governments deal with the issue. By using education as a proxy for public expenditure, finding by Gylfason (2001) shows a statistically significant nexus between natural resource abundance and low levels of educational. The paper argues that education is important for economic growth as findings showed a positive and significant link between secondary school enrolment and economic growth. The result finds support in the assumption of the endogenous growth theory that the level of human capital can have both short-run and long run impact on growth.

In another vein, natural resource abundance has been associated with rent-seeking. Rent-seeking behavior is concerned with a situation whereby highly connected individuals try to use the powers of the government to enhance their own economic welfare. With respect to the presence of natural resources, there is a tendency for countries with an abundance of it to experience massive rent-seeking among government officials and other nonstate actor elite. Rent-seeking could come in form of tariff protection or outright corruption which ends up causing distortions in the economy and thus halting the pace of growth of the economy. As noted by Auty (2001), natural resource abundance may create a false sense of security in the people as vital reforms necessary to uplift the economy are abandoned or delayed because the country can survive on export proceeds from natural resources alone. There is a direct link between rent-seeking and corruption because powerful individuals and organizations who benefit from rents can lobby to prevent political reforms so as to retain their rents. It has been observed that without any rent to protect, corrupt practices are reduced drastically. In developing countries with abundant natural resources, rent-seeking and corruption is rampant because the extraction of natural resources is usually monopolized by huge corporations or state authorities and production does not encourage competition. For instance, in Nigeria, the oil sector is dominated by the powerful international oil giants that operate directly with the government authority who grant them licenses to operate. With these monopolistic barriers, private investors find it difficult to operate in this sector.

Perhaps, the most popular among these theories is the Dutch disease syndrome theory. The Dutch disease derives its name from the experience of the Dutch that generated massive wealth after the discovery of natural gas around the 1960s, but failed to utilize the revenue to grow her economy. The aftermath of this failure was stagflation and low exports all through the 1970s. Tracing the origin of Dutch Disease, it has been observed that it begins upon the discovery of a new source of massive wealth which may not be limited to only natural resources. The exploitation of this new source of wealth results in huge profits and foreign currency. By attracting huge profits, domestic currency appreciates vis-avis the currency of trading partners. The huge profits also lead to the drawing of resources away from some vital sectors but into the boom sector for the sake of export. Consequently, earnings from the export of the boom product unduly expand national income as a whole, increasing aggregate demand. As the non-tradable industries are starved of resources, the domestic economy experiences inflationary pressure because the new source of wealth leads to increased demand and fall in the supply of non-tradable goods.

The rising prices lead to exchange rate appreciation which erodes the profits of the non-boom sector exporters. As the boom that led to the Dutch Disease evaporates, the economy begins to experience stagnation with disequilibrium in the current account and an over-valued real exchange rate. Nigeria is among the countries that has been experiencing the Dutch Disease syndrome beginning from the discovery of oil in commercial quantity. Owing to the massive revenue she generated from the sale of oil in each period the international price of oil rises, she usually embarks on ambitious projects. However, as the price of oil falls thereafter, she finds it difficult to execute most of these projects, thus leading to the problem of proliferations of abandoned projects. 
Institutions have been identified as critical in the performance of the economy. North (1990) opined that institutions comprise of formal constraints (such as rules, laws, routines and constitutions) as well as informal constraints (such as norms of behavior, conventions, self-imposed codes of conduct) and their enforcement characteristics. Institutional factors such as political, legal, economic and social have been fingered to contribute to a country's economic growth. As contended by Rodrik (1999) and Pritchett (2000) institutional quality provides long-term economic growth of countries. Linking this to natural resources and economic growth, institutional theorists contend that weak and corrupt governments attract natural resource curse. Natural resource-rich countries commonly suffer from weak institutions and this largely accounts for the reasons why, even with the abundance of natural resources in their domain, they still grapple with underdevelopment. Having explored these theories, our paper is guided by the crowding out effect of natural resource endowments on the manufacturing sector.

\subsection{Empirical Literature}

Several studies have been carried out at both country-specific and cross-country to investigate the impact of natural resource endowments on key economic variables, especially its impact on GDP.

Jalloh (2013) investigated the link between natural resource endowments and economic growth in West African countries. Under the framework of a dynamic panel estimation technique, finding indicates that natural resource endowments have very minimal impact on economic growth, especially in resource-rich West African countries. By exploring the performance of the Extractive Industries Transparency Initiative (EITI) in resourcerich countries, Meaza (2014) finds that EITI falls short of increasing the economic growth of participating countries. The study also finds that transparency without other government reforms appears to be weak in promoting economic growth in resource-rich SSA countries. In Mali, Alpha and Ding (2016) assessed the impact of natural resource endowments on economic growth over a period of 1990-2013. Under the framework of ECM, finding of the study showed that natural resources export impacts positively on growth. The paper however, finds that the interaction of natural resources export and corruption have negative impact on economic growth.

In a study for Nigeria, Amusa (2016) used ECM to investigate the link between natural resource endowments and economic growth. Finding shows that natural resources do not lead to sustained economic growth. In another cross-country study involving nine African resource-rich countries, Ayadi (2017) applied the framework of the fixed effect model with cross section as well as time dummy variables to investigate the link between natural resource endowments and GDP. The paper did not establish a significant positive impact of resource extraction on economic growth. Using an historical approach, Ali, Ella, and Iliya (2017) contended that natural resources may not be regarded as a curse to a nation, but lack of functional institutions should be blamed. The paper noted that corruption and parochialism are among the major problems of resource-rich countries such as Nigeria. Fatai et al. (2017), using data spanning a period of 1970-2016, sought to establish the link between natural resources and economic growth. Finding shows no causality between natural resource abundance and economic growth in Nigeria.

In another study for Nigeria, Raggl (2017) found that sound institutional environment and low levels of corruption are growth-enhancing effect of natural resources. The paper observed that accumulation of human and physical capital as well as the quality of institutions and natural resource rents is important ingredients for a prosperous economic development in Nigeria. Ewubare and Kakain (2017) examined the impact of natural resource abundance on economic growth in Nigeria. By decomposing different sources of natural resources, findings show that while some types of natural resources impact positively to GDP, others impacted negatively to GDP. For Nigeria also, Ayobola, Ekundayo, and Muibi (2018), using data over a period of 1981-2015 and under the framework of the ECM, showed that export diversification impacts positively on growth from the last two periods, but in the current period, it negatively effects growth. Kareem et al. (2020) examined the impact of natural resource 
endowments, human capital development and economic growth in Nigeria using time series data from 1982 to 2016. The study found natural resource endowments and human capital development to significantly affect economic growth. In a study for Kuwait, Aljarallah and Angus (2020) used data over a period of 1984 to 2014 to show that resource rents increase per capita GDP only in the short-run; however, in the long run, resource rents reduces productivity, human capital, and institutional quality

\section{ANALYTICAL FRAMEWORK}

In this study, we assume that the extent of natural resource endowments in an economy is an important determinant of its real growth rate, with particular reference to the manufacturing sector. As observed by Kronenberg (2002), many industries make use of natural resources such as iron, coal, and oil as inputs in their production process. The study noted that it is expected that the abundance of one factor input should raise the marginal product of other factors. For instance, a rise in labour input can raise the marginal product of capital input and thus contribute to economic growth. Our stance relies on the endogenous growth literature by Romer (1986) and Lucas (1988) which among others, noted that natural resources generally influence equilibrium growth rates. Having carried out a comparative study of the growth prospects of an economy with abundant natural resource endowments vis-avis that without natural resource endowments, the presence of natural resource endowments have been found to improve the prospects for growth. In another breath, we also align ourselves to the views of some economists that natural resources, even though they can lead to economic growth, can as well crowed out some vital sectors of the economy which contribute to economic growth if not well harnessed. One of these sectors is the manufacturing sector and we are of the opinion that if natural resources crowd out this sector, this has the tendency to slow down growth.

Following Aljarallah and Angus (2020), we begin the development of our analytical framework by explaining the Solow (1956) model. This model is a simplification of the analysis of the determinants of economic growth. A measure used in this analysis is to decompose the growth rate of the aggregate output between the production factors and technological changes. Equation 1 below captures a typical Solow model:

$$
Q(t)=\mathrm{A}(t) x F[K(t), L(t)
$$

where

$Q(t)=$ the level of aggregate output, $K(t)=$ the level of capital stock, $L(t)=$ the labor force , $A(t)=$ proxy for technology.

The Cobb-Douglas production function assists in specifying Equation 1 above. Arising from the empirical study of the American manufacturing industry, Paul H. Douglas and C.W. Cobb utilized the framework of the Cobb-Douglas production function in their analysis. The function is a linear homogeneous production function of degree one which models output as a function of two inputs; namely: labour and capital. Therefore, applying the framework of the Cobb-Douglas production function as an analytical base, we express this in Equation 2 as follows:

$$
Q_{t}=\mathrm{A}_{t} K_{t}^{\lambda} L_{t}^{v}
$$

Where

$Q_{t}=$ output at time t, $K=$ physical capital, $\mathrm{L}=$ labour stock (employment), $\mathrm{A}_{t}=$ efficiency level, $K$, and $\mathrm{v}$ are the output elasticity of labor and capital respectively. 
For any given level of inputs, the higher the $\mathrm{A}_{t}$, the higher the output. Under the Cobb-Douglas Production function, a constant return to scale is assumed to prevail. We can derive the expression for the output level by dividing Equation 2 above by $L$ on both sides as shown in equation 3:

$$
\frac{Q_{t}}{L_{t}}=\mathrm{A}_{t} K_{t}^{\lambda} L_{t}^{v} \frac{1}{L_{t}}
$$

If we multiply and divide Equation 3 by $L_{t}^{\lambda}$ and $L_{t}^{v}$, respectively, we arrive at the following expression in Equation 4 below:

$$
\frac{Q_{t}}{L_{t}}=\mathrm{A}\left(\frac{K_{t}^{\lambda}}{L_{t}^{\lambda}}\right) L_{t}^{\lambda}\left(\frac{L_{t}^{v}}{L_{t}^{v}}\right) L_{t}^{v} \frac{1}{L_{t}}
$$

where

$$
\frac{Q_{t}}{L_{t}}=Q_{t}, \frac{K_{t}^{\lambda}}{L_{t}^{\lambda}}=K_{t}^{\lambda}, \frac{L_{t}^{v}}{L_{t}^{v}}=1
$$

Therefore, Equation 4 becomes:

$$
Q_{t}=\mathrm{A} K_{t}^{\lambda} L_{t}^{\lambda} L_{t}^{v} \frac{1}{L_{t}}
$$

Invoking the constant return to scale assumption ( ie, $\lambda+v=1$ ) in Equation 5 , we obtain the following expression in Equation 6 below:

$$
Q_{t}=\mathrm{A}_{1}^{\lambda}
$$

where

$Q_{t}=$ output level

$K_{t}=$ physical capital stock which comprises both capital equipment and human capital stock. Taking the natural logarithm of both sides of Equation 6, we obtain the following expression in Equation 7:

$$
\ln \left(Q_{t}\right)=\ln (\mathrm{A})+\lambda \ln \left(K_{t}\right)
$$

\subsection{Conceptual Issues Arising from the Cobb-Douglas Production Function}

At this juncture, we deem it necessary to clarify certain concepts associated with the Cobb-Douglas Production function. These are as follows:

Production Function: By production function, we mean a technical relationship between the level of output and the input combinations. It shows the maximum level of output that can be obtained from the input combinations. The production function is expressed in Equation 8 below as follows:

$$
Q_{t}=f(K, L, M \ldots)
$$


where $\mathrm{Q}$ denotes the output level, $\mathrm{K}$ denotes the capital input, $\mathrm{L}$ denotes the labor input, $\mathrm{M}$ denotes the raw materials. There is a possibility of the inclusion of other variables that influence the production process and this is represented by the dots after the $\mathrm{M}$.

Production Elasticity: By definition, production elasticity $(E)$ is a percentage change in output divided by percentage change in input. It displays the ratio of the relative change in output produced to the relative change in the level of inputs employed. The output elasticity of labour (EL) is measured by the following expression in Equation 9 below:

$$
E L=\frac{\% \Delta Q}{\% \Delta L}=\lambda
$$

Where $E L=$ elasticity of labour, $\Delta Q=$ change in output, $\Delta L=$ change in labour input.

From Equation 9 above, it can be seen that the output elasticity of the labour (EL) can be measured directly through the $K$ coefficient of the Cobb-Douglas production function. On the other hand, the output elasticity of capital $(E k)$ can be measured through the following expression in Equation 10 below:

$$
E K=\frac{\% \Delta Q}{\% \Delta K}=v
$$

Where $K L=$ elasticity of capital, $\Delta Q=$ change in output, $\Delta K=$ change in capital input.

From Equation 10 above, it can be seen that the output elasticity of the capital can be measured directly through the $v$ coefficient of the Cobb-Douglas production function.

Returns to Scale: The Cobb-Douglas production function can also be used to investigate returns to scale. Returns to scale shows the relationship between percentage changes in input and output changes. Suppose the use of $K_{0}$ and $L_{0}$ will produce output $Q_{0}$ as shown in Equation 11 below:

$$
Q_{0}=\mathrm{A} L_{0}^{\lambda} K_{0}^{v}
$$

If $Q_{1}$ is an output generated by a combination of capital inputs, then it is obtained as expressed in Equation 12 below:

$$
Q_{1}=\mathrm{A} L_{0}^{\lambda} 2 K_{0}^{v}=2^{v} Q_{0}
$$

If $Q_{2}$ is the output produced by a combination of labor input, then it is obtained as expressed in Equation 13 below:

$$
Q_{2}=\mathrm{A}\left(2 L_{0}\right){ }^{\lambda} K_{0}^{v}=2^{\lambda} Q_{0}
$$

If $Q_{3}$ is the output produced by a combination of capital and labor inputs, then it is obtained as expressed in Equation 14 below:

$$
Q_{3}=\mathrm{A}\left(2 L_{0}\right)^{\lambda}\left(2 K_{0}\right)^{v}=2^{\hat{\lambda}+v} Q_{0}
$$

With these, it is obvious that if the combination of production elasticity is $\lambda+v=1$, then the function exhibits a constant return to scale, implying that increase in input will be followed by a proportional increase in output. If the combination is $\lambda+v<1$, then the function shows decreasing returns to scale, implying that a percentage 
increase in output arising from a percentage increase in input is smaller. If $\lambda+v>1$, this means an increasing returns to scale which indicates a rise in output that is greater than the percentage increase in input.

\subsection{Model Specification}

The model for our study is guided by the modification of Equation 7 of the analytical framework as specified in Equation 15 below:

$$
M V A_{t}=f\left(N R R_{t}, \text { GFCF }_{t}, \text { EMPIND }_{t}, \text { RINTR }_{t}, \text { TOPEN }_{t}, I N F L R_{t}, \mu_{t}\right)
$$

where

$M V A_{t}=$ Manufacturing value added at time t, $N R R_{t}=$ Natural resource rent at time t, $G F C F_{t}=$ Gross fixed capital formation at time t, $E M P I N D_{t}=$ Employment in industry at time t, RINTR $_{t}=$ Real interest rate at time

t, $T O P E N_{t}=$ Trade openness at time $\mathrm{t}, I N F L R_{t}=$ Inflation rate at time $\mathrm{t}$ and $\mu_{t}=$ error term.

We employed the framework of the autoregressive distributed lag (ARDL) bounds model by Pesaran, Shin, and Smith (2001) and Pesaran and Shin (1999) in estimating Equation 15 above. Since the variables exhibited a mixture of $\mathrm{I}(1)$ and $\mathrm{I}(0)$ and the sample size is small, the ARDL framework is more suitable in this study. In the application of the model, a dynamic unrestricted error correction model (UECM) can be derived through a simple linear transformation. The UECM combines the short-run dynamics with the long-run equilibrium without losing any long-run information. The ARDL can be expressed in Equation 16 as follows:

$$
\begin{aligned}
& \Delta M V A_{t}=\varphi_{0}+\sum_{i=1}^{t} \Psi_{i} \Delta M V A_{t-1}+\sum_{i=1}^{t} \Theta_{i} \Delta N R R_{t-1}+\sum_{i=1}^{t} \vartheta_{i} \Delta G F C F_{t-1}+\sum_{i=1}^{t} \gamma_{i} \Delta E M P I N D_{t-1}+\sum_{i=1}^{t} \xi_{t} \Delta R I N T R_{t-1}+ \\
& \sum_{i=1}^{t} \theta_{t} \Delta T O P E N_{t-1}+\sum_{i=1}^{t} \pi_{1} \Delta I N F L R_{t-1}+\delta_{1} M V A_{t-1}+\delta_{2} N R R_{t-1}+\delta_{3} G F C F_{t-1}+\delta_{4} \text { EMPIND }_{t-1}+\delta_{54} R_{N} I N R_{t-1}+ \\
& \delta_{6} \operatorname{TOPEN}_{t-1}+\delta_{7} I \operatorname{INLR}_{t-1}+\mu_{t}
\end{aligned}
$$

where $\varphi_{0}$ is the drift component and $\Psi, \Theta, \vartheta, \gamma, \xi, \theta$ and $\pi$ are the short run parameters while the $\delta_{1}, \delta_{2}$,

$\delta_{3}, \delta_{4}, \delta_{5}, \delta_{6}$ and $\delta_{7}$ are the long-run parameters. To obtain the long-run relationship between the dependent and independent variables, a Wald restriction test is used. With the hypothesis expressed below, the $F$-statistic test assists to determine whether a co-integration exists or not.

The long-run hypothesis is stated as follows:

$$
\begin{aligned}
& H_{0}=\delta_{1}=\delta_{2}=\delta_{3}=\delta_{4}=\delta_{5}=\delta_{6}=\delta_{7}=0 \text { (No co-integration) } \\
& H_{1}=\delta_{1} \neq \delta_{2} \neq \delta_{3} \neq \delta_{4} \neq \delta_{5} \neq \delta_{6} \neq \delta_{7} \neq 0 \text { (Existence of co-integration) }
\end{aligned}
$$

The estimated $F$ statistic value is compared with two critical values, namely: the lower bounds critical values $I(0)$ and the upper bounds critical values $I(1)$. If the calculated F-statistics exceeds the upper bound critical value, a long-run relationship is said to exist. However, if the calculated F-statistics falls below the lower critical values, there is an absence of co-integration. Finally, if the calculated F-statistic falls between the two critical bounds, the result is inconclusive. With the existence of a long-run relationship between the dependent and independent variables, an error correction representation of the model (ECM) is estimated and this is specified in Equation 17 below: 


$$
\begin{aligned}
& \Delta M V A_{t}=\varphi_{0}+\sum_{i=1}^{t} \psi_{i} \Delta M V A_{t-1}+\sum_{i=1}^{t} \Theta_{i} \Delta N R R_{t-1}+\sum_{i=1}^{t} \vartheta_{i} \Delta G F C F_{t-1}+\sum_{i=1}^{t} \gamma_{i} \Delta \text { EMPIND }_{t-1}+\sum_{i=1}^{t} \xi_{t} \Delta R I N T R_{t-1}+ \\
& \sum_{i=1}^{t} \theta_{t} \Delta \text { TOPEN }_{t-1}+\sum_{i=1}^{t} \pi_{1} \Delta I N F L R_{t-1}+\Omega E C M_{t-1}+\mu_{t}
\end{aligned}
$$

where

$E C M_{t-1}=$ Error correction model

$\Omega=$ Coefficient of error correction model

The coefficient of $E C M_{t-1}$ indicates the speed of adjustment of the short-run shocks toward the long-run equilibrium in the case of any disturbance and it is expected to be negative and significant.

\subsection{Variables for the Study}

We employed annual data over a period of 1990-2019 and data on all the variables were obtained from the World Development Index. We used manufacturing value added to proxy the performance of the manufacturing sector. Manufacturing value added (MVA) of an economy has been defined by the United Nations Industrial Development Organization (UNIDO) as "the total estimate of net-output of all resident manufacturing activity units obtained by adding up outputs and subtracting intermediate consumption”. Our major attraction for this proxy is because it is more attuned to natural resources since in its calculation, it does not allow for the depletion and degradation of natural resources. Following Ayadi (2017), we used total natural resource rent as a percentage of GDP to proxy natural resources endowment. Total natural resources rents are the sum of oil rents, natural gas rents, coal rents (hard and soft), mineral rents, and forest rents. Also, following Ayadi (2017) and other studies, we used Gross fixed capital formation as a percentage of GDP to proxy capital stock. Gross fixed capital formation deals with expenditure on land improvements which include fences, ditches, and drains, among others. It also comprises spending on plant, equipment and machinery. Data on gross fixed capital formation are in constant local currency unit (LCU). Employment in industry is used to proxy the contribution of the labour force to the manufacturing sector. Most studies use different proxies for labour force such as labour force participation rate, secondary school enrolment rate (Alpha \& Ding, 2016), etc. However, since our interest is on the contribution of labour to manufacturing, we thought it necessary to adopt a proxy that closely captures labour's contribution. We used real interest rate to proxy interest rate. Real interest rate is nominal interest rate adjusted for inflation. Annual rate of inflation was used to proxy inflation. Following Alpha and Ding (2016); Ayadi (2017) and Fatai et al. (2017), we used trade openness to represent the role of international trade and it is calculated as the ratio of the sum of export and import to GDP. Current local currency unit of export, import and GDP was used in the calculation of trade openness.

\section{INTERPRETATION OF RESULTS AND DISCUSSION OF FINDINGS}

In this sub-section, the results of the study are displayed and discussed.

\subsection{Tests for Stationarity}

In other to ensure that the series behave well so as not to run into the problem of spurious regression, we first conducted unit root test. We carried out this test with respect to Augmented Dickey Fuller (ADF) and PhilipPeron (PP) and the evaluation was done at the $5 \%$ and $10 \%$ level of significance respectively. From the results in Table 2 below, we observed that at level, MVA and NRR achieved stationarity, while real RINTR achieved stationarity when evaluated under the PP. Other variables did not achieve stationarity at level. However, after first 
difference as shown in Table 3 below, all the series achieved stationarity. The implication of the results indicate that the series exhibited an admixture of $\mathrm{I}(0)$ and $\mathrm{I}(1)$.

Table-2. Result of Stationarity at Level.

\begin{tabular}{c|c|c|c|c|c}
\hline Variables & ADF t-stat. & PP t-stat. & $\begin{array}{c}\text { ADF Critical } \\
\text { value at 5\% }\end{array}$ & $\begin{array}{c}\text { PP Critical } \\
\text { value at 5\% }\end{array}$ & $\begin{array}{c}\text { Order of } \\
\text { integration }\end{array}$ \\
\hline MVA & $-3.567410^{*}$ & $-3.567410^{*}$ & 0.0130 & 0.0130 & $\mathrm{I}(\mathrm{O})$ \\
\hline NRR & $-2.748111^{* *}$ & $-2.797247^{*} *$ & 0.0784 & 0.0710 & $\mathrm{I}(0)$ \\
\hline GFCF & -2.204880 & -2.116546 & 0.2089 & 0.2399 & \\
\hline EMPIND & -1.654850 & -7.959156 & 0.0000 & 0.4423 & \\
\hline RINTR & -2.091064 & $-3.225627^{*}$ & 0.2495 & 0.0286 & PP I $(0)$ \\
\hline TOPEN & 0.494762 & -1.917202 & 0.9834 & 0.3201 & \\
\hline INFLR & -2.027583 & -2.291676 & 0.2740 & 0.1812 & \\
\hline
\end{tabular}

Note: * and ** indicate the rejection of the null hypothesis at the $5 \%$ and $10 \%$ level respectively.

Table-3. Result of Stationarity at first difference.

\begin{tabular}{c|c|c|c|c|c}
\hline Variables & ADF t-stat. & PP t-stat. & $\begin{array}{c}\text { ADF Critical } \\
\text { value at 5\% }\end{array}$ & $\begin{array}{c}\text { PP Critical } \\
\text { value at 5\% }\end{array}$ & $\begin{array}{c}\text { Order of } \\
\text { integration }\end{array}$ \\
\hline$\Delta \mathrm{MVA}$ & $-7.143911^{*}$ & $-10.36152^{*}$ & 0.0000 & 0.0000 & $\mathrm{I}(1)$ \\
\hline$\Delta \mathrm{NRR}$ & $-7.235854^{*}$ & $-13.34050^{*}$ & 0.0000 & 0.0000 & $\mathrm{I}(1)$ \\
\hline GFCF & $-3.615766^{*}$ & $-3.660989^{*}$ & 0.0119 & 0.0107 & $\mathrm{I}(1)$ \\
\hline$\Delta \mathrm{EMPIND}$ & $-47.90707^{*}$ & $-32.85173^{*}$ & 0.0001 & $\mathrm{I}(1)$ & $\mathrm{I}(1)$ \\
\hline$\Delta \mathrm{RINTR}$ & $-4.089021^{*}$ & $-4.089021^{*}$ & 0.0041 & 0.0041 & $\mathrm{I}(1)$ \\
\hline$\Delta$ TOPEN & $-9.359089^{*}$ & $-9.335549^{*}$ & 0.0000 & 0.0000 & $\mathrm{I}(1)$ \\
\hline \multicolumn{2}{|l|}{ Note: $*$ indicates the rejection of the null hypothesis at the $1 \%}$. & & & 0.0020 &
\end{tabular}

\subsection{ARDL Bounds Test}

With the results of stationarity showing a mixture of $\mathrm{I}(\mathrm{O})$ and $\mathrm{I}(1)$, we proceeded to test for the existence of cointegration among the variables. We investigated this using the ARDL Bounds test as shown in Table 4 below. At the $5 \%$ level, the F-statistic was compared with both the upper and lower critical values. The following conditions below assisted us in making the decision: if the value of the F-stat. is higher than the upper critical bound I(1), the existence of co-integration is confirmed. However, if the value of the F-stat. is lower than the critical bound $\mathrm{I}(0)$, the series are not co-integrated. From the results displayed in Table 4 below, the F-stat. is 10.81388 which is greater than the upper critical bound (3.28) at the 5\% level of significance. Consequently, we confirm the presence of cointegration among the series. This result is further confirmed by the result of the Error Correction Model (ECM) in Table 5 below which shows a negative coefficient that is statistically significant. With this result, we went ahead to investigate both short run and long run impacts.

Table-4. ARDL Bounds test results.

\begin{tabular}{l|c|c}
\hline \multicolumn{1}{c|}{ Test Statistic } & Value & K \\
\hline F-statistic & 10.81388 & 6 \\
\hline Critical Value Bounds & & Upper Bound I $(1)$ \\
\hline Significance & Lower Bound I $(0)$ & 2.94 \\
\hline $10 \%$ & 1.99 & 3.28 \\
\hline $5 \%$ & 2.27 & 3.61 \\
\hline $2.5 \%$ & 2.55 & 3.99 \\
\hline $1 \%$ & 2.88 & \\
\hline
\end{tabular}

\subsection{Short and Long Run Results of ARDL}

The results of the short-run as shown in table 5 below indicate that without a lag, natural resources positively and significantly impact on manufacturing valued added, however, after a one period lag, the impact of natural resources on manufacturing value added turns negative and it is significant. The current period result confirms the 
observation by Romer (1986) and Lucas (1988) that the presence of natural resources endowment can improve the prospects for growth. On other hand, the negative impact of natural resources on manufacturing value added after a lag indicates that natural resources crowd out manufacturing sector in Nigeria. Over reliance on the oil sector in Nigeria has led to the neglect of vital sectors of the economy such as the manufacturing sector and this has resulted in the low performance of the manufacturing sector. Finding of the result shows that even though the gross fixed capital formation is positively related to manufacturing value added, its impact is not significant. This result goes a long way to prove that capacity utilization of capital assets is low in Nigeria that they cannot impact on the manufacturing sector. In the short-run also, the impact of real interest rate on manufacturing valued added is found to be negative and significant. High interest rate is a phenomenon in Nigeria which is among the factors militating against the performance of the manufacturing sector. Even when the monetary authorities are persuaded to reduce the rate, this is not possible because of the existence of high inflation. The impact of employment in industry on manufacturing value added is positive and significant which shows that labour force is a veritable factor that influences the performance of the manufacturing sector. The result of the impact of inflation on manufacturing value added is negative and significant. Rising inflation results in rising cost of production as prices of inputs become expensive. This situation affects the export price of the domestically produced goods, making them uncompetitive internationally. Trade openness is negatively related to manufacturing value added even though it is not significant. This result shows that import of manufacture has a tendency to displace export of manufacture. The Nigerian manufacturing sector is mainly comprised of light goods which usually has substitutes at the international market. Owing to this, the terms of trade in manufacture is usually not favourable, especially if the country is a high cost producer. In the long-run, we noticed that natural resources contribute positively and significantly to the manufacturing valued added. However, the result of the impact of gross fixed capital formation shows that it negatively and significantly impacts on the manufacturing value added. This long-run result confirms the finding by Nzeh (2020) that showed a negative link between gross fixed capital formation and GDP in Nigeria which further confirms our earlier observation concerning the low capacity utilization of capital assets. What we find curious is the positive link between real interest rate and the manufacturing value added in the long-run. A possible plausible reason we can advance is that manufacturing firms in Nigeria are taking advantage of the rising interest rate to investment in high yielding debt instruments and other interest bearing investment outlets. The results of inflation rate, employment in industry and trade openness in the long-run follow the apriori expectations.

Table-5. ARDL long run and short run results of the relationship between NRR and MVA.

\begin{tabular}{|c|c|c|c|c|}
\hline Variable & Coefficient & Std. Error & t-Statistic & Prob. \\
\hline \multicolumn{5}{|l|}{ Short-run results } \\
\hline $\mathrm{D}(\mathrm{NRR})$ & 0.991930 & 0.402522 & 2.464286 & 0.0314 \\
\hline $\mathrm{D}(\mathrm{NRR}(-1))$ & -1.127278 & 0.356714 & -3.160177 & 0.0091 \\
\hline $\mathrm{D}(\mathrm{GFCF})$ & 0.747496 & 0.629936 & 1.186621 & 0.2604 \\
\hline $\mathrm{D}(\operatorname{RINTR}(-1))$ & -0.606667 & 0.216086 & -2.807534 & 0.0170 \\
\hline D(EMPIND) & 12.75374 & 4.730567 & 2.696027 & 0.0208 \\
\hline D(EMPIND(-1)) & 1.221815 & 0.557590 & 2.191243 & 0.0509 \\
\hline $\mathrm{D}$ (INFLR) & -0.715546 & 0.154648 & -4.626941 & 0.0007 \\
\hline DLOG(TOPEN) & -7.264073 & 6.881037 & -1.055665 & 0.3138 \\
\hline $\operatorname{ECM}(-1)$ & -1.462120 & 0.125302 & -11.66873 & 0.0000 \\
\hline \multicolumn{5}{|l|}{ Long run results } \\
\hline $\operatorname{NRR}(-1)$ & 3.097929 & 0.830762 & 3.729022 & 0.0033 \\
\hline $\operatorname{GFCF}(-1)$ & -0.702217 & 0.311705 & -2.252827 & 0.0457 \\
\hline RINTR(-1) & 1.157605 & 0.412813 & 2.804185 & 0.0171 \\
\hline EMPIND(-1) & 5.138654 & 2.875403 & 1.787107 & 0.1015 \\
\hline $\operatorname{INFLR}(-1)$ & -0.393526 & 0.152870 & -2.574258 & 0.0259 \\
\hline LOG(TOPEN(-1)) & 6.280351 & 7.366918 & 0.852507 & 0.4121 \\
\hline $\mathrm{C}$ & -270.0731 & 233.0974 & -1.158628 & 0.2711 \\
\hline
\end{tabular}




\subsection{Post Diagnostic Tests}

In other to ensure the robustness of our results, we tested for serial correlation, heteroskedasticity, normality of the series, model specification and the stability of the coefficients. From Table 6 below, findings show that there is an absence of a serial correlation, heteroskedasticity and that the model is well specified. We also noticed that the errors are normally distributed and the plot of cumulative sum (CUSUM) and the cumulative sum of squares (CUMSUM of Squares) displayed in Appendixes 1 and 2 below indicate the absence of any instability of the coefficients. This is because the plot of the CUSUM and CUSUMSQ statistic is found inside the critical bands of the $5 \%$ confidence interval.

Table-6. Robustness Test.

\begin{tabular}{l|c|c|c}
\hline Test & P-value & Null Hypothesis & Conclusion \\
\hline $\begin{array}{l}\text { Heteroskedasticity Test: Breuch-Pegan - } \\
\text { Godfrey }\end{array}$ & 0.9981 & $\mathrm{H}_{0}$ : No Homoscedasticity & Cannot reject $\mathrm{H}_{0}$ \\
\hline Serial Correlation: Breusch-Godfrey LM Test & 0.0848 & $\mathrm{H}_{0}$ : No Serial Correlation & Cannot reject $\mathrm{H}_{0}$ \\
\hline Normality Test: Jargue-Bera & 0.8537 & $\mathrm{H}_{0}$ : Normally Distributed & Cannot reject $\mathrm{H}_{0}$ \\
\hline Ramsey RESET Test: Model Specification & 0.3458 & $\mathrm{H}_{0}$ : Correctly Specified & Cannot reject $\mathrm{H}_{0}$ \\
\hline
\end{tabular}

\section{CONCLUSION AND RECOMMENDATIONS}

In this paper, we sought to investigate the link between natural resource endowment and the performance of the manufacturing sector. We are motivated by the poor performance of the manufacturing sector in Nigeria and the theoretical postulation that natural resources can crowd- out the manufacturing sector. Under the framework of an ARDL and over a period of 1990-2019, our findings showed that in the short-run, natural resources positively impact on the manufacturing value added in the current period, however, after a one period lag, the contribution of natural resources to the manufacturing value added becomes negative. Also, in the short-run, real interest rate, inflation rate and trade openness are negatively linked to the manufacturing value added, while employment in industry and gross fixed capital formation are positively related to the manufacturing value added. The long-run results show that natural resources impact positively on the manufacturing value added just as gross fixed capital formation and inflation rate negatively impact on the manufacturing valued added.

The implication of the findings of the study is that natural resources rent can act as a buffer to the manufacturing sector and can as well crowed-out the sector. Based on the foregoing, we recommend that the proceeds from natural resources should be utilized properly by building critical infrastructure necessary to improve the performance of the manufacturing sector. The era of monetizing all the proceeds from natural resources, especially revenues from oil should stop. Even though we believe that increased productivity has the tendency to lower inflation and hence, interest rate, we suggest that both fiscal and monetary policies should be fine-tuned in order to reduce the cost of production. It is also our view that policies on human capital development should be pursued so as to have an abundance of well-trained labour, just as institutional factors that impinge on the manufacturing sector should be upgraded. Much as it is expected that restrictions on importation could improve the export prospect of the country, we caution that the country should not be in a haste to carry out policies in that respect. This is because of the tendency of such policies to cause further inflation. The current experience in the country where the placing of a ban on some essential commodities led their prices to shoot up should serve as a lesson to policy makers in the country. The local production of these commodities cannot meet the domestic demand, thus leading to increased prices.

Funding: This study received no specific financial support.

Competing Interests: The authors declare that they have no competing interests.

Acknowledgement: All authors contributed equally to the conception and design of the study. 


\section{REFERENCES}

Ali, M., Ella, S. O., \& Iliya, S. M. (2017). Resource endowment and poverty in Nigeria. IOSR Journal of Economics and Finance, $8(5), 37-43$.

Aljarallah, R. A., \& Angus, A. (2020). Dilemma of natural resource abundance: A case study of Kuwait. Sage Open, 10(1), 2158244019899701 . Available at: https://doi.org/10.1177/2158244019899701.

Alpha, B. B., \& Ding, Y. (2016). A study on the impact of natural resources endowment on economic growth: Empirical evidence from Mali. Journal of Economics and Development Studies, 4(4), 81-103.

Amusa, J. (2016). Economic growth paradox in Nigeria: A perspective from natural resource wealth time series analysis for the period 1980-2013. An M.Sc Thesis Submitted to The Graduate School, Eastern Illinois University, Charleston, Illinois.

Auty, R. M. (2001). The political economy of resource-driven growth. European Economic Review, 45(4-6), 839-846. Available at: https://doi.org/10.1016/s0014-2921(01)00126-x.

Ayadi, F. S. (2017). Resource endowment and economic growth in selected African countries. Journal of Management and Social Sciences, 6(2), 284-302.

Ayobola, C., Ekundayo, M., \& Muibi, S. (2018). Resource endowment and export diversification: Implications for growth in Nigeria. Studies in Business and Economics, 13(1), 29-40. Available at: https://doi.org/10.2478/sbe-2018-0003.

Ewubare, D. B., \& Kakain, S. (2017). Natural resource abundance and economic growth in Nigeria (1980-2015). Global Journal of Agricultural Research, 5(3), 1-11.

Fatai, O. O., Adeolu, B. I., \& Ayo, A. D. (2017). Natural resources abundance and economic growth nexus in Nigeria. International Journal of Innovative Finance and Economics Research, 5(4), 52-65.

Gylfason, T. (2001). Natural resources, education, and economic development. European Economic Review, 45(4-6), 847-859.

Jalloh, M. (2013). Natural resources endowment and economic growth. JNRD-Journal of Natural Resources and Development, 3(2013), 66-84.

Kareem, R. O., Arije, R. A., Zakariyah, A. O., \& Avovome, Y. H. (2020). Natural resources endowment, human capital development and economic growth in Nigeria. Izvestiya Journal of Varna University of Economics, 64(1), 26-46.

Kronenberg, T. (2002). The curse of natural resources in the transition economies. Arbeiten aus dem Osteuropa-Institut München Working Paper No. 241.

Lucas , R. E. (1988). On the mechanics of economic development. Journal of Monetary Economics, 22(1), 3-42.

Meaza, Z. D. (2014). The natural resource curse in Sub-Saharan Africa: Transparency and International Initiatives. An Abstract of a Dissertation Submitted to the Graduate School of The University of Southern Mississippi.

North, D. C. (1990). Institutions, institutional change, and economic performance. New York: Cambridge University Press.

Nwaogwugwu, I., Ayodele, S., \& Ejumedia, P. (2016). Nigeria's industrial policy and its binding constraints in Nwokoma and Ishola (edited), Nigeria's industrial development, corporate governance and public policy. Lagos: Unilag Press and Bookshop Ltd.

Nzeh, I. C. (2020). Public debt and economic growth in Nigeria: Investigating the optimal threshold level. Asian Development Policy Review, 8(2), 112-127.

Okorafor, A. O. (2014). Developing indigenous technology for harnessing local natural resources in Nigeria: The place of technical vocational education and training. International Journal of Science and Technology, 3(8), 461-466.

Pesaran, M., \& Shin, Y. (1999). An autoregressive distributed-lag modelling approach to co- integration analysis. Cambridge: Cambridge University Press.

Pesaran, M., Shin, Y., \& Smith, R. (2001). Bounds testing approaches to the analysis of level relationships. Journal of Applied Econometrics, $16(3)$, 289-326. Available at: https://doi.org/10.1002/jae.616.

Pritchett, L. (2000). Understanding patterns of economic growth: Searching for hills among plateaus, mountains, and plains. The World Bank Economic Review, 14(2), 22 1-250. Available at: https://doi.org/10.1093/wber/14.2.221.

Raggl, A. K. (2017). Natural resources, institutions and economic growth: The case of Nigeria. Policy Research Working Paper No. 8153 . 
Rodrik, D. (1999). Where did all the growth go? External shocks, social conflicts, and growth collapses. Journal of Economic Growth, 4(4), 385-412.

Romer, P. M. (1986). Increasing returns and long run growth. Journal of Political Economy, 94(3), 1002-1037. Available at: https://doi.org/10.1086/261420.

Sachs, J. D., \& Warner, A. M. (2001). The curse of natural resources. European Economic Review, 45(4-6), 827-838.

Solow, R. M. (1956). A contribution to the theory of economic growth. Quarterly Journal of Economics, 70(1), 65-94.

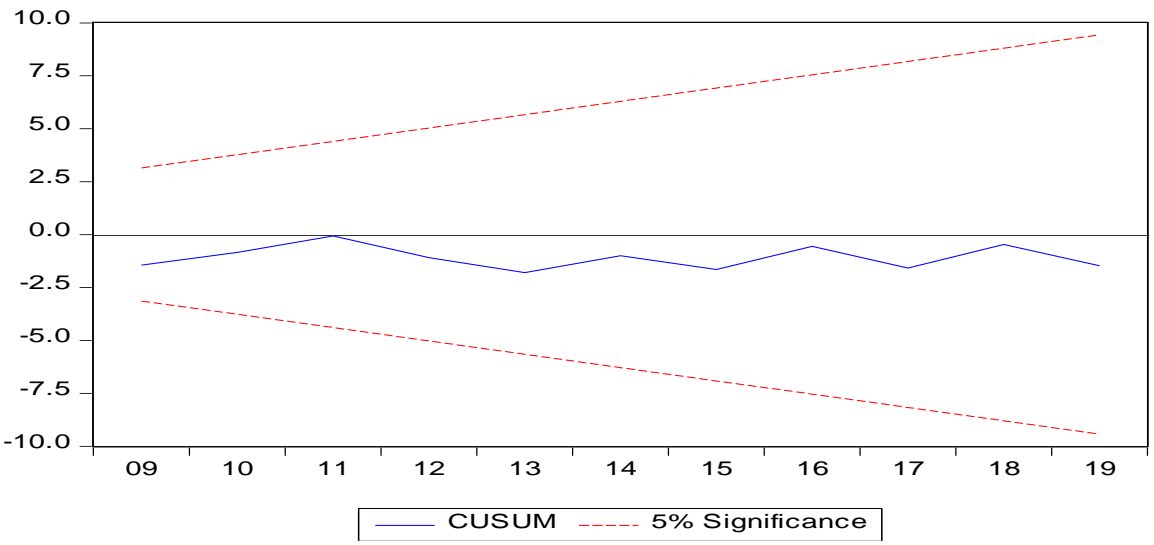

Appendix-1. Plot of cumulative sum of recursive residuals.

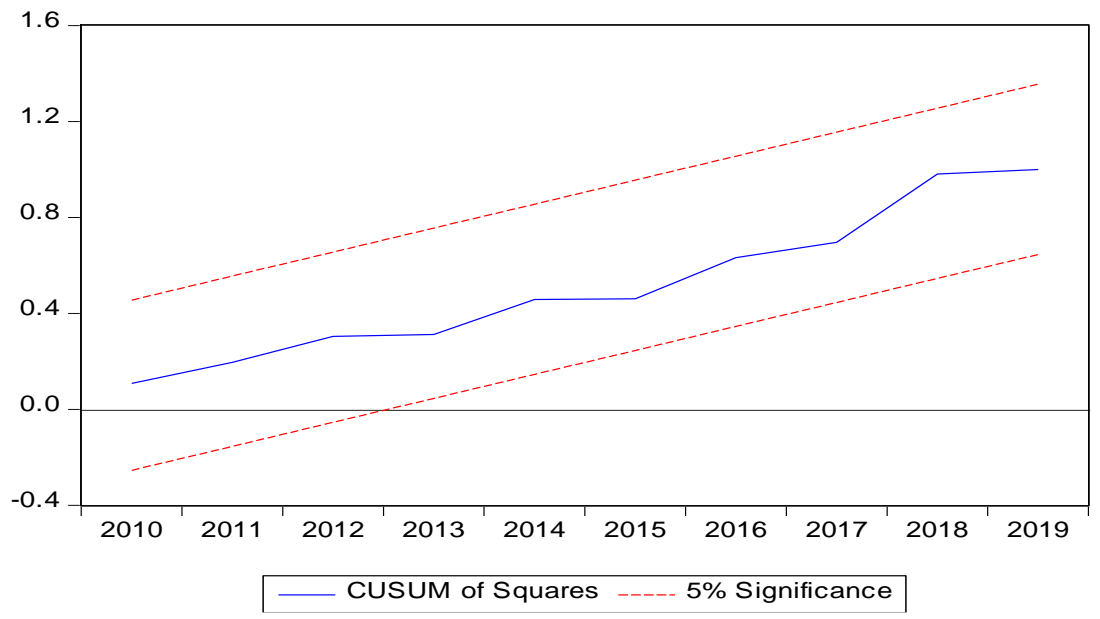

Appendix-2. Plot of cumulative sum of squares of recursive residual.

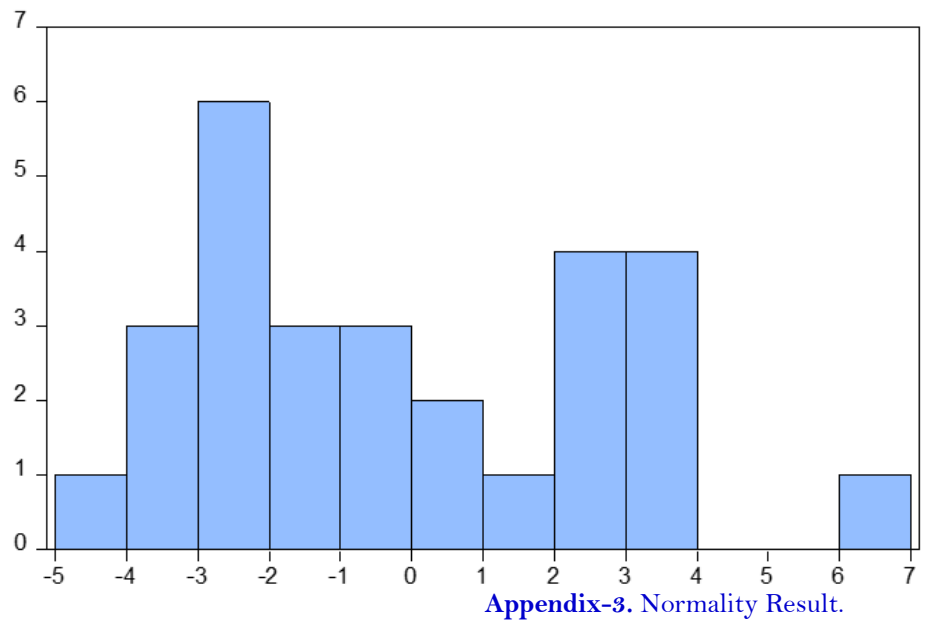

Series: Residuals Sample 19922019

Observations 28

Mean $\quad 3.04 \mathrm{e}-14$

Median $\quad-0.582942$

Maximum $\quad 6.222937$

Minimum $\quad-4.030281$

Std. Dev. $\quad 2.825540$

Skewness $\quad 0.426549$

Kurtosis $\quad 1.954771$

Jarque-Bera 2.123659

Probability $\quad 0.345823$ 
Asian Development Policy Review, 2021, 9(3): 108-126

Appendix-4. Time required to get electricity (days).

\begin{tabular}{|c|c|c|c|c|c|c|}
\hline 2013 & 2014 & 2015 & 2016 & 2017 & 2018 & 2019 \\
\hline \multicolumn{7}{|c|}{ NIGERIA } \\
\hline 149.44 & 149.44 & 149.44 & 149.44 & 149.44 & 115.33 & 109.8 \\
\hline \multicolumn{7}{|c|}{ BOSTWANA } \\
\hline 121 & 121 & 77 & 77 & 77 & 77 & 77 \\
\hline \multicolumn{7}{|c|}{ CONGO DEMOCRATIC REPUBLIC } \\
\hline 101 & 55 & 46 & 44 & 44 & 44 & 44 \\
\hline \multicolumn{7}{|c|}{ SIERRA LEONE } \\
\hline 113 & 82 & 82 & 82 & 82 & 82 & 82 \\
\hline \multicolumn{7}{|c|}{ MAURITANIA } \\
\hline 75 & 75 & 70 & 67 & 67 & 67 & 67 \\
\hline \multicolumn{7}{|c|}{ ZAMBIA } \\
\hline 117 & 117 & 117 & 117 & 117 & 117 & 117 \\
\hline
\end{tabular}

Appendix-5. Time to export, documentary compliance (in hours)

\begin{tabular}{|c|c|c|c|c|c|}
\hline 2014 & 2015 & 2016 & 2017 & 2018 & 2019 \\
\hline \multicolumn{6}{|c|}{ NIGERIA } \\
\hline 131.4 & 131.4 & 131.4 & 131.4 & 119 & 74 \\
\hline \multicolumn{6}{|c|}{ BOSTWANA } \\
\hline 24 & 24 & 24 & 18 & 18 & 18 \\
\hline \multicolumn{6}{|c|}{ CONGO DEMOCRATIC REP. } \\
\hline 347 & 515 & 515 & 515 & 296 & 296 \\
\hline \multicolumn{6}{|c|}{ SIERRA LEONE } \\
\hline 227.1 & 227.1 & 227.1 & 227.1 & 227.1 & 227.1 \\
\hline \multicolumn{6}{|c|}{ MAURITANIA } \\
\hline 58.7 & 58.7 & 50.7 & 50.7 & 50.7 & 50.7 \\
\hline \multicolumn{6}{|c|}{ ZAMBIA } \\
\hline 72 & 130 & 130 & 96 & 95 & 96 \\
\hline
\end{tabular}

Appendix-6. Ease of doing business.

\begin{tabular}{|c|c|c|c|c|c|}
\hline 2015 & & 2016 & 2017 & 2018 & 2019 \\
\hline & \multicolumn{5}{|c|}{ NIGERIA } \\
\hline \multirow[t]{2}{*}{48.37466} & & 48.47451 & 52.02699 & 53.40471 & 56.87589 \\
\hline & \multicolumn{5}{|c|}{ BOSTWANA } \\
\hline \multirow[t]{2}{*}{65.48306} & & 65.64189 & 65.71078 & 66.17048 & 66.1978 \\
\hline & \multicolumn{5}{|c|}{ CONGODEMOCRATC REP. } \\
\hline \multirow[t]{2}{*}{34.35533} & & 34.39028 & 34.57002 & 35.23313 & 36.20973 \\
\hline & \multicolumn{5}{|c|}{ SIERRA LEONE } \\
\hline \multirow[t]{2}{*}{47.21918} & & 47.21918 & 47.08868 & 47.24268 & 47.45831 \\
\hline & \multicolumn{5}{|c|}{ MAURITANIA } \\
\hline \multirow[t]{2}{*}{43.75791} & & 46.88194 & 48.44839 & 49.37674 & 51.06288 \\
\hline & \multicolumn{5}{|l|}{ ZAMBIA } \\
\hline 60.45046 & & 60.25434 & 64.23311 & 65.7117 & 66.93648 \\
\hline
\end{tabular}

Note: $\mathrm{o}=$ lower performance, $100=$ best performance.

Views and opinions expressed in this article are the views and opinions of the author(s), Asian Development Policy Review shall not be responsible or answerable for any loss, damage or liability etc. caused in relation to/arising out of the use of the content. 